\title{
Peculiarities of Pupils and Vocational College Students' Career Guidance Modeling in the Integrated System "School - College - Enterprise"
}

\author{
Kadriya Ildashevna Sibgatova ${ }^{1}$, Suriya Irekovna Gilmanshina ${ }^{2}$, Fidaliya Damirovna Khalikova ${ }^{2}$, Iskander \\ Rafailevich Gilmanshin ${ }^{2}$, Ilsia Rafailevna Akchurina ${ }^{2}$, Nataliya Georgiyevna Shchaveleva ${ }^{2}$ \& Guzel \\ Rafkatyevna Fassakhova ${ }^{3}$ \\ ${ }^{1}$ Technical College at Kazan National Research Technical University named after A. N. Tupolev, Russia \\ ${ }^{2}$ Kazan (Volga region) Federal University, Russia \\ ${ }^{3}$ Kazan State Agrarian University, Russia \\ Correspondence: Kadriya Ildashevna Sibgatova, Technical College at Kazan National Research Technical \\ University named after A.N. Tupolev, Kazan, 420111, Russia. E-mail: baina@techcol.kstu-kai.ru
}

Received: October 9, 2014 Accepted: November 14, 2014 Online Published: December 2, 2014

doi:10.5539/ass.v11n1p386 URL: http://dx.doi.org/10.5539/ass.v11n1p386

\begin{abstract}
The article is aimed at the development of theoretical and applied model of career guidance work with pupils and vocational college students in the integrated system "school - college - enterprise". The integrative, competence and personality oriented approaches are the main approaches in researching this problem. They were directed at the organization of career guidance work with pupils and vocational college students in the integrated system. The theoretical and applied model of career guidance work with pupils and vocational college students in the integrated system "school - college - enterprise" presented in the article includes the following units: theoretical and methodological, functional and purpose oriented, substantial, technological, methodical and criteria estimated. Materials of the article can be used by schools teachers and teachers of vocational educational institutions while planning career guidance work at the educational institutions.
\end{abstract}

Keywords: career guidance modeling, integrated system, school, college, enterprise, pupils, students

\section{Introduction}

The necessity for school and vocational college integration implementation of career guidance work arises from situation that a pupil becomes a student. It leads to his status change, to new training conditions transition and new life conditions. The college can't help considering this goal of high school. Integration of these educational institutions should be considered as regularity, the principle, process and a way of a conflict resolution between special college tasks and comprehensive type of high school training

Model of career guidance work in the integrated system "school - vocational college - enterprise" must present the processes aimed at the work in this system. Speaking of the processes directed at career guidance work, we should consider the problems concerning continuity of these processes because the absence of these problems shows that the model is incapable to predict their sequence. So using the model won't solve a problem of the current situation aimed at the development of this or that branch of the processes (Gilmanshina, 2007).

Now there are a number of the problems that slow down the joint solution of the task by the subjects of integrated system. They are:

- lack of stable communication between educational institutions and employers, their poor engagement in the developing of professional and educational standards, in participating in work of trustee (supervisory) councils of educational institutions, in systems of corporate training forming, etc. (Helfman et al., 2009);

- lack of reasonable strategy development of productive power, mechanisms of labor market demands accounting that slow down the formation of the state system of specialists training. It does not allow adapting it for market conditions while training staff with necessary qualification (Masalimova, 2012); 
- inefficient legislative and regulatory base of educational system development, including uninterrupted education;

- insufficient attention paid to improvement of educational process development at all types of educational institutions;

- inefficient career guidance activity at educational institutions (Vasilyeva, 1993).

All parts of system "school - vocational college - enterprise" have constant essential changes and therefore the model doesn't always use all opportunities necessary for the whole system. However the model is urged to display most precisely the main idea of the union of this system. That is why the system was created for. The purpose of the integrated system doesn't limit means, opportunities and abilities of each system element and also promotes their mutual potential growth. For example, it is possible to outline the following items in the integrated system "school - vocational college - enterprise":

- it is important for school that the pupils acquire that amount of qualities and abilities which would help them to gain independence in choosing this or that profession most precisely;

- it is necessary for vocational college to get pupils with suitable qualities and abilities that allow them getting into this or that profession;

- enterprises need qualified staff, capable to use their professional qualities and abilities to solve modern actual problems of production.

Therefore, the maximum development of these pupils' qualities and abilities must become the main means of the purpose achievement of each element of the integrated system "school - vocational college - enterprise. It allowed us to define the reasoning of creating pedagogical model of career guidance work with pupils and students in the integrated system "school - vocational college - enterprise".

\section{Materials and Methods}

Integrative, competence and personality-oriented approaches are in a basis of theoretical and applied model of career guidance work with pupils in the integrated system "school - vocational college - enterprise".

Integrative approach assumes interpenetration of functions of the system subjects while developing the model of career guidance work in the integrated system "school - vocational college - enterprise. It allows reorganization of the structure for the coordinated interaction with each other in order to increase the efficiency of joint career guidance work (Masalimova \& Shaidullina, 2006).

The necessity of competence approach is caused by the fact that career guidance work, besides knowledge, skills, is directed at experience of practical activities acquisition. Pupils receive more and more developed practice of application of educational information as the means of activity forms implementation while changing one form of educational activity for another. It allows gaining of real practical activities experience and having an opportunity of natural coming into profession (Zeyer, 2004).

Personality-oriented approach is used in the organization of career guidance work with pupils in the integrated system "school - vocational college - enterprise". It means placing the emphasis on skills to form the personality that is capable to use technology of creative activity but not to accumulate the ready knowledge. The activity reflex broadens considerably the functional sphere of pupils and allows forming personal responsibility for their activity results.

We relied on the principles (their account is necessary) of career guidance introduction in the integrated system "school - vocational college - enterprise" while developing the model of career guidance work with pupils in the integrated system "school - vocational college - enterprise". The research considered the following principles:

- principle of functional compatibility assuming interpenetration and coherence of the subjects' functions of integrated system "schools - vocational college - enterprise" for optimum use of joint resources solving career guidance tasks;

- the principle of compliance to the regional requirements, assuming personnel needs accounting of the region in training specialists who have vocational education;

- the principle of continuity assuming succession in the contents and technologies of career guidance work, continuity of career guidance stages with pupils and students, system and sequence requirements toward a school leaver; 
- the principle of the integration assuming unity and coherence of structural and substantial components of career guidance work with pupils and students in integrated system "school - vocational college - enterprise" (Sibgatova, 2010).

The main functions of career guidance work in the integrated system "school - vocational college - enterprise" are the following: coordinating, assuming coordination of subjects' activity in integrated system "school vocational college - enterprise" in the development of career guidance work with pupils. Predictive function assumes realistic forecast of parameters of the integrated system "school - vocational college - enterprise" development. It also assumes an assessment of the entrants' amount to college, acquired specialties demanded for career guidance work to search alternative sources to keep usual amount of college students' contingent. Information and methodical function assume the development of this system and methodical recommendations improve career guidance work by the subjects and also their informing at institutions of general and vocational education. This function assumes inclusion of the system subjects into joint studying of students' professional interests and research of their motivation to choose a definite profession (Sibgatova, 2011).

\section{Results}

The theoretical and methodical unit of model includes combination of approaches (integrative, competence and personality-oriented); principles (functional compatibility, compliance to regional requirements, continuity, integration); functional and purpose-oriented. It aimed at formation of conscious choice of profession taking into account requirements of a regional labor market. Its tasks are to form professional self-determination; methodical help in a choice of an individual educational and career way; formation of students' adaptation abilities; assistance to graduates in employment, etc.). Functions (coordinating, predictive, informational and methodical, diagnosing); the main directions of joint activity of subjects of this system (coordination of subjects activity of the studied system in elaboration of strategy of their interaction); correctional activities of the subjects of this system for the development of career guidance work to improve it; the organization of system of professional development of the subjects of the integrated system "school - vocational college - enterprise".

The substantial unit includes content development of complex actions of career guidance direction at organizational, information, diagnostic and methodical levels among pupils and students, carried out by subjects of the integrated system "school - vocational college - enterprise"

- contracts on joint cooperation between "Technical college" and more than 10 schools of Kazan are signed at organizational level; parents, former graduates, representatives of the enterprises, the institutions and firms are involved in career guidance work with pupils; maintenance departments of future professional career for pupils and vocational college students are created; "Open Days" are held at college; they visit schools of Kazan, the republic, nearby regions, cultural entertainment complexes, the enterprises. Meetings of pupils and their parents are organized by representatives of various professions; excursions to the enterprise are organized as well; career guidance competitions are held;

- information level assumes establishment of regular communication with headmasters of Kazan schools; development of an advertizing and information material about specialties, regulations of admission, forms and training college conditions; distribution of an advertizing and information material among pupils of schools and gymnasiums; carrying out systematic informing about current state of application results of Unified State Examination at entering professional educational institutions; giving lectures on career guidance; participation of college teachers in PTA meetings at schools with career guidance reports; informing pupils about territorially available institutions of additional education, about possibility of participation in competitions, grants, etc.;

- diagnostic level of career guidance actions assumes updating of diagnostic material for studying students' interests, tendencies, abilities, educational inquiries, their psycho-physiological features, readiness for training in the chosen directions and specialties; creation of specialized psycho-diagnostic techniques to use them in the career guidance; inclusion of each pupil into the sphere promoting interests and tendencies development: clubs and other extracurricular classes at college; registration of career guidance " case" for all pupils where their compositions about profession choice, the completed questionnaires, the questionnaires revealing interests and tendencies, the documents reflecting results of supervision over pupils, etc. will be kept;

- there is an updating of curricula and syllabus of career guidance elective courses at methodical level; there is creation of new methodical materials for organizing work practice; mentoring, pupils and students' training to choose the direction of their further education ; use of specialized psychological and pedagogical literature, methodical recommendations and literature for teachers and parents; providing the libraries with educational, methodical, diagnostic and career guidance reference materials, etc. 


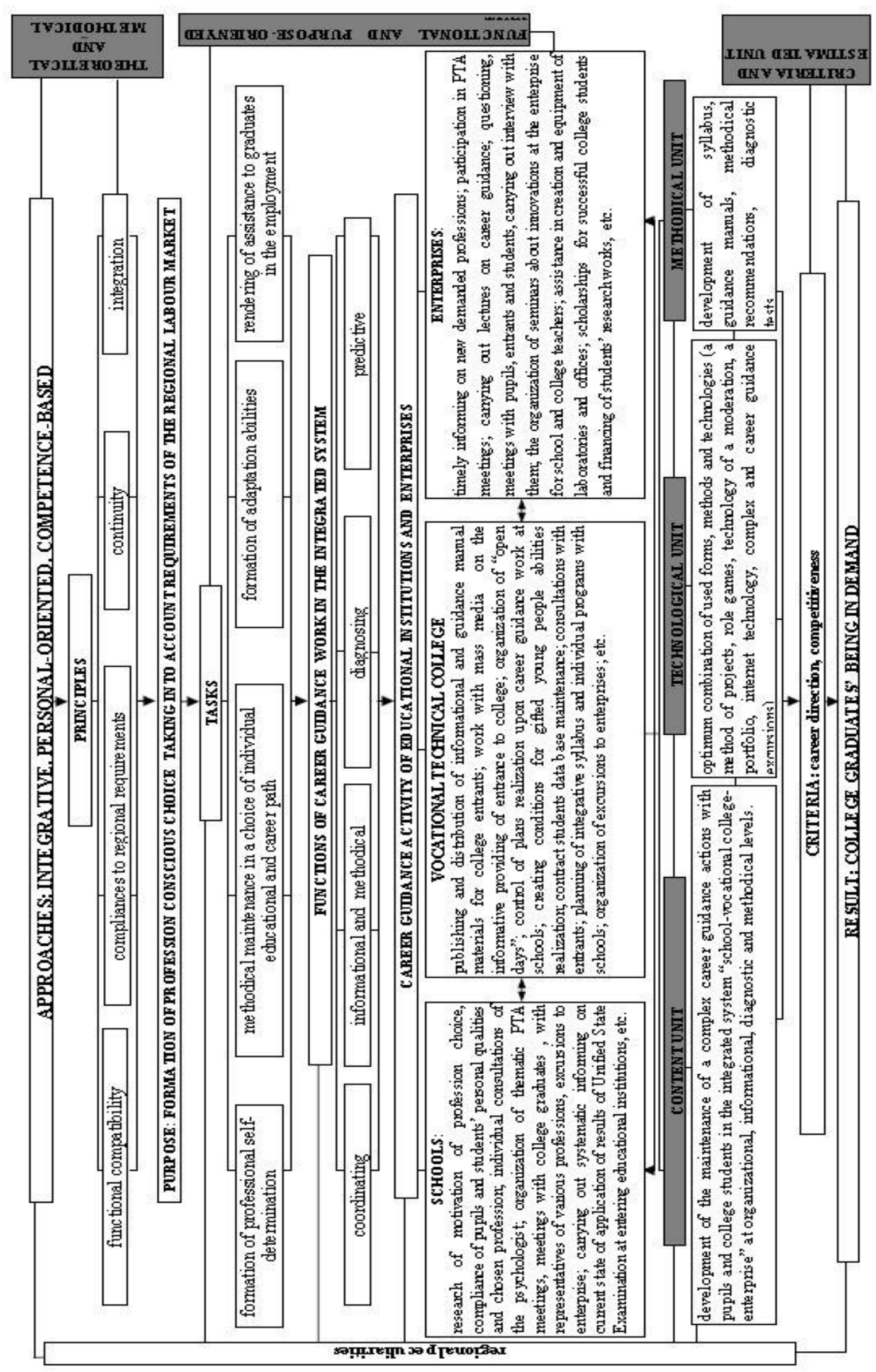

Figure 1. Theoretical and applied model of career guidance work with pupils and students in the integrated system "school-vocational college-enterprise" 
The technological unit of model offered by us assumes an optimum combination of used forms, methods and technologies (a method of projects, role games, a portfolio, internet technologies, complex and career guidance excursions) in career guidance work with pupils and vocational college students in the integrated system "school - vocational college - enterprise". This model is aimed at increasing pupils' activity in the process of making decision and responsibility understanding while choosing their future profession.

The methodical unit of career guidance model with pupils in the integrated system "school - vocational college - enterprise" presents educational and methodical retraining and professional development of the subjects of this system providing the introduction of joint career guidance work with pupils. It includes a training syllabus and a guidance manual "The theory and practice of career guidance work in the integrated system "school - vocational college - enterprise", methodical recommendations for improving career guidance work with pupils.

The criteria and estimated unit of this model presents the components of effective career guidance work with pupils in the integrated system "school - vocational college - enterprise".

The main criterion of modern career guidance model correctness is its ability to correspond a common purpose of the integrated system "school - vocational college - enterprise" where the solution of tasks has consolidating character and is directed on joint work not for differentiation of the jurisdiction with available potential of the subjects of this integrated system, but for usage optimization of available resources while solving these tasks.

\section{Discussions}

Problems of career guidance and professional self-determination are investigated in works of many Russian and foreign scientists, in particular: problem of pupils' career guidance are revealed by S. S. Grinshpun, 2004; N. Zakharov, 1988; E. A. Klimov, 2007; N. S. Pryazhnikov, 2008; A. S. Prutchenkov, 2001, etc.; motives and factors of pupils' professional self-determination are investigated by A. Maslow, 1999; S. N. Chistyakova, 1993, etc.; problems of professionally-oriented labor in the system of uninterrupted education are identified by N. A. Aitov, 2009; S. Y. Batyshev, 1999, etc.; foreign adaptive educational potential organization of pupils' career guidance is revealed by S. S. Grinshpun, 2005; G. V. Shchekin, 2003; Y. V. Ukke, 1990, etc. The various problems of pupils' career guidance work are discussed in the thesis. In particular: peculiarities of the organization of career guidance in uninterrupted education are discussed by (Khmeleva, 2002); theoretical and methodological basis for the Pedagogical institutes students' readiness formation for pupils' career guidance work are developed by (Pshenichnov, 2009); organizational and pedagogical conditions of effective professional self-determination of high school pupils are established and developed by (Andreeva, 2010; Shcherbakov, 2006). However, analysis of the scientific and educational literature on research topic and practical activity experience suggest that scientific and methodological subjects of educational institutions and professional community training in the implementation of joint pupils' career guidance isn't currently developed.

\section{Conclusion}

Thus, the theoretical-applied model of career guidance work developed by us with pupils and students in the integrated system "school - vocational college - enterprise", presents the combination of the following units: theoretical and methodological (approaches, principles), functional and purpose ( purposes, tasks, functions, directions of joint career guidance work of the subjects studied system), substantial ( content of actions of organizational, informational, diagnostic and methodical levels), technological ( optimum combination of forms, methods and technologies used in career guidance work with pupils), methodical (syllabuses, guidance manuals, methodical recommendations, diagnostic tests directed on optimization of career guidance work with pupils in integrated system "school - vocational college - enterprise"), criteria and estimated (components of effective career guidance work with pupils in the integrated system "school - vocational college - enterprise").

Distinctive peculiarity of the offered model is its multidimensionality and efficiency of receiving result. It depends on the fact that it is directed at joint activity with the definite directions of career guidance work not for differentiation of the jurisdiction of the available subjects' potential of the integrated system, but for optimization of joint resources usage while solving career guidance tasks in the integrated system "school vocational college - enterprise".

\section{References}

Aitov, N. A. (1999). About subjectivity and subjectivity. Case Studies, 9, 110-113.

Andreeva, L. I. (2010). Professional self schoolchildren in the innovation activities of educational institution (Thesis PhD, p. 178). Togliatti.

Batyshev, S. Y. (2009). Professional Pedagogy. Association "Vocational Education", Moscow. 
Chistyakova, S. N. (1993). Professional self-determination and career development of young people. Moscow.

Gilmanshina, S. I. (2007). Professionally directed thinking - the basis of competence of the teacher. Higher Education in Russia: scientific and pedagogical journal Defense and H Federation, 4, 159-160.

Grinshpun, S. S. (2005). Professional orientation of students in the United States. Pedagogy, 9, 65-72.

Helfman, E. G., Holodnaya, M. I., Bashirova, I. A., \& Blinov, T. L. (2009). Modern problems of education: theory and practice (p. 298). Ural State Pedagogical University Press.

Khmeleva, E. V. (2002). Vocational guidance work with students in continuing education (Thesis PhD, p. 162). Stavropol.

Klimov, E. A. (2007). Psychology professional self: a textbook for high schools (p. 304). Academy, Moscow.

Masalimova, A. R. (2012). Competency Model of modern mentor. Vocational education in Russia and abroad, 4(3), 104-107.

Masalimova, A. R., \& Shaidullina, A. R. (2006). Prospets for the use of foreign experience training engineers in the Russian system of vocational education. Proceedings of the higher educational institutions. Problems of energetic, 5-6, 85-92.

Maslow, A. (1999). Motivation and Personality (p. 322). Eurasia, St. Petersburg.

Prutchenkov, A. S. (2001). Socio-psychological training in school (p. 640). Moscow: Eksmo-Press.

Pshenichnov, A. N. (2009). Formation of readiness for career-oriented work with students of pedagogical high school students (Thesis PhD, p. 124). Shuya.

Shchekin, G. V. (2003). Theory and practice of human resource management (p. 87). AIDP.

Shcherbakova, T. V. (2006). Support of professional self-pupils of the city as the organizational and pedagogical problem (Thesis PhD, p. 190). Novgorod.

Sibgatova, K. I. (2010). Professional adaptation of future technical specialists in the integration of educational institutions and enterprises customers frames. Kazan Pedagogical Journal, 3, 99 - 105.

Sibgatova, K. I. (2011). Model of career guidance in an integrated system "school - college - enterprise". Kazan Pedagogical Journal, 1, 83-90.

Ukke, Y. (1990). Diagnosis conscious choice of profession among Japanese schoolchildren. Questions of Psychology, 5, 150-151.

Vasilyeva, Z. I. (1993). Way interaction of educational theory and practice in the teaching of high school. Formation individual teacher in continuing teacher education (pp. 4-9). Syktyvkar.

Zakharov, N. N. (1988). Professional orientation of students (p. 134). Education, Moscow.

Zeyer, E. F., Pavlova, A. M., \& Sadovnikova, N. O. (2004). Proforientology: Theory and Practice (p. 215). Yekaterinburg.

\section{Copyrights}

Copyright for this article is retained by the author(s), with first publication rights granted to the journal.

This is an open-access article distributed under the terms and conditions of the Creative Commons Attribution license (http://creativecommons.org/licenses/by/3.0/). 